\title{
Seasonal and latitudinal dependencies of phytoplankton carbon-to-chlorophyll a ratios: results of a modelling study
}

\author{
Arnold H. Taylor ${ }^{1, *}$, Richard J. Geider ${ }^{2}$, Francis J. H. Gilbert ${ }^{1}$ \\ ${ }^{1}$ Plymouth Marine Laboratory, Prospect Place, West Hoe, Plymouth PL1 3DH, United Kingdom \\ ${ }^{2}$ Marine Biological Association of the United Kingdom, The Laboratory, Citadel Hill, Plymouth PL1 2PB, United Kingdom
}

\begin{abstract}
A realistic description of acclimation of the growth rate and carbon-to-chlorophyll $a$ ratio $(\mathrm{C}: \mathrm{chl}$ a) of phytoplankton to irradiance, nitrate concentration and temperature was incorporated into a 1-dimensional model of phytoplankton production dynamics. The properties of the model's steadystates are described as a guide to its behaviour and to parameter sensitivity. Seasonal cycles of chlorophyll $a$ and $\mathrm{C}: \mathrm{chl} a$ within the upper $200 \mathrm{~m}$ of the ocean were predicted at latitudes ranging from $0^{\circ}$ to $60^{\circ} \mathrm{N}$. Although limited to a consideration of physiological acclimation of a single taxon, our results compared well with observations. Predicted values of $\mathrm{C}$ : chl a ranged from 20 to $>160 \mathrm{~g} \mathrm{C} \mathrm{g}^{-1} \mathrm{chl} \mathrm{a}$. Lowest values of $\mathrm{C}: \mathrm{chl}$ a were predicted for the top of the nutricline within the seasonal thermocline in mid-summer. Highest values of $\mathrm{C}$ : chl a were predicted for the nutrient-depleted surface mixed layer in mid-summer. The seasonal range of $\mathrm{C}$ : chl a was greatest in tropical and subtropical waters and least at $60^{\circ} \mathrm{N}$. Predictions of the vertical distribution of $\mathrm{C}: \mathrm{chl}$ a at $20^{\circ} \mathrm{N}$ were consistent with published observations for the subtropical North Pacific Ocean. Predictions of the relationship between $\mathrm{C}$ : chl $a$ and chlorophyll $a$ in surface waters showed qualitative agreement with published observations for the North Atlantic Ocean. The value of $\mathrm{C}: \mathrm{chl} a$ within the surface mixed layer depends on the mean irradiance within the surface mixed layer and the extent of draw-down of the limiting nutrient (nitrate) from winter/spring maxima. A balance between phytoplankton growth and loss to grazing led to quasisteady-state conditions in the mixed layer in summer. Parameterisation of grazing was a critical determinant of summer $\mathrm{C}$ : chl a. Another critical parameter was the physiologically determined minimum value of $\mathrm{C}: \mathrm{chl}$ a. Implications of physiological acclimation of $\mathrm{C}: \mathrm{chl}$ a to our understanding of the role of phytoplankton in the ocean carbon cycle are discussed.
\end{abstract}

KEY WORDS: Phytoplankton $\cdot$ Chlorophyll $\cdot$ Modelling $\cdot$ Carbon $\cdot$ Seasonal $\cdot$ Latitudinal

\section{INTRODUCTION}

Chlorophyll $a$ is the most widely employed measure of phytoplankton abundance. However, it is the carbon content of phytoplankton that is required for calculating growth rate from ${ }^{14} \mathrm{C}$ uptake measurements (Eppley 1972, Longhurst et al. 1995) and for evaluating the role of phytoplankton in the carbon cycle and marine food webs. It has long been recognised that the carbon-to-chlorophyll a ratio $(\mathrm{C}: \mathrm{chl}$ a) is a major unknown variable that limits our understanding of

•E-mail: a.h.taylor@pml.ac.uk marine ecosystems (Strickland 1960, Eppley 1972, Banse 1977). Variability of $\mathrm{C}$ : chl a of phytoplankton has been documented using new instrumentation and techniques, including flow cytometry to estimate phytoplankton carbon content (Campbell et al. 1994, Buck et al. 1996), and ${ }^{14} \mathrm{C}$ labelling of chlorophyll $a$ to estimate phytoplankton growth rates and carbon content (Redalje \& Laws 1981, Gieskes \& Kraay 1989, Goericke \& Welschmeyer 1993)

The carbon:chlorophyll a ratio varies from about 12 to $>200 \mathrm{~g} \mathrm{~g}^{-1}$ in phytoplankton cultures. Fortunately, $C$ :chl a does not vary randomly. Rather it is highly regulated in response to irradiance, nutrient 
availability and temperature (Goldman 1980, Langdon 1988a, b, Falkowski \& La Roche 1991, Geider 1987, 1993, Cloern et al. 1995, Geider et al. 1997) It is minimal at high temperatures $\left(25\right.$ to $\left.30^{\circ} \mathrm{C}\right)$ and low irradiances $\left(<20\right.$ umol photons $\mathrm{m}^{-2} \mathrm{~s}^{-1}$ ) under nutrientreplete conditions and increases at high irradiances, especially at low temperature and under nutrient-limiting conditions. A recent regulatory model (Geider et al. 1997) can account for much of the systematic variability of $\mathrm{C}$ :chl a in phytoplankton. The model includes the reduction of cell pigment content at high irradiance. The decline of pigment content is exacerbated when growth rate is limited by low temperature or restricted nutrient availability. In this paper we embed this regulatory model into a simplified 1 dimensional model of primary production and so generate predictions for the temporal and spatial variations of $\mathrm{C}$ : chl $\mathrm{a}$.

Míodeis of pelagic ecosystems commoniy depict phytoplankton growth as a multiplicative function of light, nutrient and temperature effects (e.g Tett et al. 1986, Fasham et al. 1990, Taylor et al. 1993). Most of these models do not account for the nonlinear responses to these environmental factors arising from adjustments to $\mathrm{C}: \mathrm{chl}$ a. Although Kiefer \& Kremer (1981), Kiefer (1993) and Doney et al. (1996) included acclimation of chlorophyll $a$ in their models, they did not present predictions of variations in $\mathrm{N}$ :chl a or C:chl $a$, nor did they compare predictions with observations. The regulation of $\mathrm{N}$ :chl $a$ in these models is qualitatively similar to our treatment of $\mathrm{C}$ : chl a. However, the Kiefer \& Kremer (1981) and Doney et al. (1996) models require knowledge of $\mathrm{N}$ : chl a for cells in balanced growth in order to specify the dynamics of physiological acclimation. The model employed here (Geider et al. 1997) yields C:chl $a$ in both balanced and unbalanced growth as a consequence of physiological dynamics rather than as an input.

The present study uses the model of Geider et al. (1997) to determine how $C$ : chl a ratios may be expected to vary with latitude and season in the ocean. The 1-dimensional physical structure employed has been kept as simple as possible in order to highlight the roles of the physiological processes. The steadystate properties of a 2-layer version of the model are described to illustrate the behaviour of the model during the summer or at the equator and demonstrate some of the parameter sensitivity. Parameter values for the environmental forcing functions have been selected to be representative of different latitudes. We show that the model reproduces most aspects of the seasonally and latitudinally distributed observations, examine the sensitivity of the results to changes in the structure and parameters of the model, and discuss the implications of the results.

\section{THE MODEL}

The model, which is based on Taylor et al. (1986), describes the annual variations of the vertical distributions of phytoplankton and a single nutrient (inorganic nitrogen as nitrate and/or ammonium) down a 1dimensional ocean water column. Irradiance at the sea surface was calculated for any latitude and time of the year by the appropriate astronomical formulae and a correction for reflection applied as in Bunker (1976). Annual cycles of light, temperature and vertical mixing down the water column are specified using the parameter values given in Tables 1 \& 2 . Phytoplankton growth rate is calculated by the relationships used by Geider et al. (1997). The phytoplankton are subject to a time-dependent specific loss rate $(m)$ due to death or respiration, which regenerates the nutrient with efficiency $\varepsilon$. Particulate carbon, chlorophyll a and dissolved nutrient are calculated as functions of depth $(z)$ and time $(t)$. Phytoplankton cells sink at a rate $(v)$ within a hydrodynamic regime defined by the spatially and temporally variable turbulent diffusion coefficient $K(z, t)$. Upweling or downwelling are not considered in the present calculations. The changes in carbon $(C)$, chlorophyll $a(a)$ and nutrient $(N)$ concentrations are then described by:

$$
\begin{aligned}
& \frac{\partial C}{\partial t}=P^{C} C-m C-v \frac{\partial C}{\partial z}+\frac{\partial}{\partial z}\left[K(z, t) \frac{\partial C}{\partial z}\right] \\
& \frac{\partial a}{\partial t}=\rho_{c h i} P^{C} C-m a-v \frac{\partial a}{\partial z}+\frac{\partial}{\partial z}\left[K(z, t) \frac{\partial a}{\partial z}\right] \\
& \frac{\partial N}{\partial t}=-\gamma\left(P^{C} C-\varepsilon m C\right)+\frac{\partial}{\partial z}\left[K(z, t) \frac{\partial N}{\partial z}\right]
\end{aligned}
$$

where $P^{C}$ is the carbon-specific photosynthesis rate, $\rho_{\mathrm{Cin}^{7}}$ is the ratio of chlorophyll a synthesis to carbon fixation and $\gamma$ is the conversion factor from $\mathrm{mg} \mathrm{C}$ to $\mathrm{mMN}$ (based on a $\mathrm{C}: \mathrm{N}$ ratio of 5.6 ).

Boundary conditions at the surface and bottom are also needed to constrain the model. As there can be no flux across the sea-surface:

and.

$$
\begin{gathered}
K(z, t) \frac{\partial C}{\partial z}=v C, \quad K(z, t) \frac{\partial a}{\partial z}=v a \\
K(z, t) \frac{\partial N}{\partial z}=0
\end{gathered}
$$

must hold at the surface. At the bottom, $C$ and $a$ are set to zero and $N$ is assigned a constant value. This allows phytoplankton to sediment out and nutrient to return to the water column from below. The sinking velocity has been set to zero in all the calculations which follow.

The vertical variation of the turbulent diffusion coefficient $K(z, t)$ in the ocean is represented by means of a 2-layer approximation. In the mixed layer $K$ was assumed to be $0.02 \mathrm{~m}^{2} \mathrm{~s}^{-1}$, while beneath the mixed 
Table 1. Parameters of the phytoplankton growth model

\begin{tabular}{|c|c|c|c|}
\hline Parameter & Symbol & Units & Value \\
\hline Chlorophyll a specific initial slope of $P$-I curve & $\alpha_{c h l}$ & $\mathrm{gC}(\mathrm{g} \mathrm{chl})^{-1}(\mu \mathrm{mol} \text { phot. })^{-1}$ & 0.0000075 \\
\hline Activation energy & $E_{\mathrm{a}}$ & $\mathrm{J} \mathrm{mol}^{-1}$ & 70000 \\
\hline Half saturation constant of Monod equation & $K_{N}$ & $\mu \mathrm{M}$ & 0.1 \\
\hline Maximum photosynthesis rate at the reference temperature & $P$ MAX & $d^{-1}$ & 2.25 \\
\hline Universal gas constant & $R$ & $\mathrm{~J} \mathrm{~mol}^{-1} \mathrm{~K}^{-1}$ & 8.3 \\
\hline Maximum chlorophyll a:carbon ratio & $\theta_{m}$ & $g$ chl $(g C)^{-1}$ & 0.05 \\
\hline Reference temperature & $T_{r+1}$ & $\mathrm{~K}$ & 293 \\
\hline
\end{tabular}

Table 2. Environmental parameters

\begin{tabular}{|c|c|c|c|c|c|c|}
\hline Parameter & Units & $0^{\circ} \mathrm{N}$ & $25^{\circ} \mathrm{N}$ & $35^{\circ} \mathrm{N}$ & $47^{\circ} \mathrm{N}$ & $60^{\circ} \mathrm{N}$ \\
\hline Winter mixed-layer depth & $\mathrm{m}$ & 20 & 155 & 210 & 320 & 520 \\
\hline Summer mixed-layer depth & $\mathrm{m}$ & 20 & 20 & 20 & 25 & 40 \\
\hline Winter temperature & ${ }^{\circ} \mathrm{C}$ & 26 & 21 & 20 & 14 & 9 \\
\hline Summer temperature & ${ }^{\circ} \mathrm{C}$ & 26 & 26 & 26.5 & 20 & 13 \\
\hline Bottom temperature & ${ }^{\circ} \mathrm{C}$ & 19 & 18.5 & 19.5 & 14 & 9 \\
\hline Attenuation of red light & $\mathrm{m}^{-1}$ & 0.4 & 0.4 & 0.4 & 0.4 & 0.4 \\
\hline Attenuation of green light & $m^{-1}$ & 0.035 & 0.04 & 0.04 & 0.06 & 0.095 \\
\hline Attenuation due to chl a & $\mathrm{m}^{2}(\mathrm{~g} \mathrm{chl})^{-1}$ & 0.012 & 0.012 & 0.012 & 0.012 & 0.012 \\
\hline Nutrient at bottom & $\mu \mathrm{M}$ & 2 & 2 & 2 & 8 & 8 \\
\hline Winter specific loss rate & $d^{-1}$ & 0.2 & 0.15 & 0.1 & 0.1 & 0.05 \\
\hline Summer specific loss rate & $d^{-1}$ & 0.2 & 0.2 & 0.2 & 0.2 & 0.2 \\
\hline
\end{tabular}

layer a value of $5 \times 10^{-5} \mathrm{~m}^{2} \mathrm{~s}^{-1}$ was used. These values were selected to be typical of many regions of the ocean. At each latitude and each day of the year the mixed-layer depth was estimated as in Taylor et al. (1991). The annual cycle from Levitus (1982) was employed at $35^{\circ} \mathrm{N}$. At other latitudes, the same shape was used, but rescaled with different maximum and minimum values (Table 2).

Vertical mixing from the sea surface is not constant during the day but fluctuates as the buoyant convection varies (Woods \& Barkmann 1986). While wind mixing stirs the upper 10 to $20 \mathrm{~m}$ at all times of the day, the convection due to surface cooling penetrates deeper and is more variable. At night, convection reaches throughout the mixed layer; but during most of the day the heat input by the sun exceeds the heat loss by evaporation, sensible heat flux and long-wave radiation, so that convection only extends to a shallow depth. This diurnal variation can be important to the onset of the spring bloom (Taylor \& Stephens 1993). To take account of the additional convection at night, the mixed layer was homogenised at the beginning of each day.

The organic carbon-specific photosynthesis rate $\left(P^{c}\right)$ is expressed as a function of the irradiance (I) and the chlorophyll a: carbon ratio $(\theta)$ as follows (Geider et al. 1997), using the parameter values given in Table 1 :

$$
P^{C}=P_{m l}^{C}\left[1-\exp \left(\frac{\alpha_{\mathrm{chl}} I \theta}{P_{m}^{C}}\right)\right]
$$

where $\alpha_{\text {chl }}$ is the initial slope of the $P-I$ curve normalised to chlorophyll $a$, and $P_{m}^{C}$ is the light-saturated rate of photosynthesis normalised to carbon. The initial slope is assumed to be constant based on 2 simplifications: first, that the rate of light absorption is proportional to chlorophyll a content, and second, that the maximum quantum efficiency of photosynthesis is invariant (Geider et al. 1997). The light intensity at any depth is calculated by splitting the light into red and green bands as in Taylor et al. (1991). $P_{m}^{C}$ is considered to be a multiplicative function of a Monod nutrient limitation function and an Arrhenius temperature dependence:

$$
P_{m}^{C}=P_{\mathrm{MAX}}^{C}\left[\frac{N}{N+K_{N}}\right] \exp \left[-\frac{E_{\mathrm{a}}}{R}\left(\frac{1}{T}-\frac{1}{T_{\text {ref }}}\right)\right]
$$

where $P_{m}^{c}$ is the maximum photosynthesis rate allowed by a given temperature $(T)$ and nutrient concentration $(N), T_{\text {rel }}$ is a reference temperature of $293 \mathrm{~K}, P_{\text {Max }}$ is the reference value of $P_{m}^{C}$ at $T_{\text {ref }}$ under nutrient-replete conditions, $K_{N}$ is the half saturation constant for growth and $E_{\mathrm{d}} / R$ is the slope of an Arrhenius plot.

The temperature in the mixed layer is assumed to vary sinusoidally between an assigned winter (midFebruary) minimum and an assigned summer (mid- 
August) maximum. The temperature at the bottom boundary is kept at a constant value throughout the year. Temperatures at intermediate depths were obtained by linear interpolation between the bottom of the mixed layer and the bottom boundary.

$\rho_{\text {chl }}$ is assumed to be regulated by the ratio of achieved-to-maximum potential photosynthesis (Geider et al. 1997):

$$
\rho_{c h l}=\theta_{m}\left(\frac{p^{C} C}{\alpha_{c h l} I a}\right)=\theta_{m}\left(\frac{P^{C}}{\alpha_{c h l} I \theta}\right)
$$

where $\theta_{m}$ is the maximum chlorophyll a: carbon ratio observed in cells acclimated to extremely low light. $\rho_{\text {chi }}$ declines when the instantaneous light harvesting capacity (i.e. $\alpha_{c h l} I \theta$ ) exceeds the instantaneous photosynthesis rate.

The specific loss rate $(m)$ arising from death and respiration varies sinsoidally between a winter minimum and a summer maximum which occur in the middie of February and the middle of August. The recycling efficiency $(\varepsilon)$ is assumed to be a function of the nutrient concentration so as to accommodate the expectation that recycling will be much more efficient when nutrient becomes depleted:

$$
\varepsilon=0.3+\frac{0.65 K_{N}}{N+K_{N}}
$$

$\varepsilon$ varies from 0.3 when nutrients are in excess to 0.95 when nutrients are absent. We arbitrarily chose to scale the $N$ dependence of the recycling efficiency by the value $K_{N}$. Other scaling factors could have been employed to yield qualitatively similar results. Eq. (8) incorporates the observation that the ratio of newto-regenerated production (the so-called f-ratio) is related to the nutrient concentration (Platt \& Harrison 1985).

Eqs. (1) to (3) were solved (see Appendix A) by means of the Crank-Nicholson method using an implicit treatment of the nutrient limitation terms as in Taylor et al. (1986). However, before describing the results, we will discuss the equilibrium properties of the model. These illustrate the behaviour and parameter sensitivity of the model during the summer period and at the equator, occasions when there is the greatest vertical variability in $\mathrm{C}$ : chl a.

\section{STEADY-STATE PROPERTIES OF THE MODEL}

Following Taylor et al. (1986) and Taylor (1988), the properties of the steady-states of Eqs. (1) to (3), can be demonstrated by approximating the system by 2 layers: a mixed layer in which carbon, chlorophyll $a$ and nutrient concentrations are $C_{M}, a_{M}$ and $N_{M}$, and a thermocline layer in which these values are $C_{T}, a_{T}$ and $N_{\mathrm{T}}$. Beneath these 2 layers is a deep layer in which there is no phytoplankton and the nutrient concentration is fixed at $N_{\mathrm{B}}$. The population in the mixed layer is assumed to be nutrient limited while that in the thermocline is assumed to be light limited. The dependence of each limiting factor is taken to be linear. In order to facilitate the analysis, self-shading of the phytoplankton is neglected. Numerical experiments have shown that removal of this assumption does not change the basic conclusions. In the 2 layers, $P^{C}$ and $\rho_{\text {chl }}$ from Eqs. (5) to (7) reduce to:

$$
\begin{aligned}
& P_{\mathrm{M}}^{C}=\beta_{M} N_{\mathrm{M}} \\
& P_{\mathrm{T}}^{C}=\alpha_{\text {chl }} I_{\mathrm{T}} \frac{a_{\mathrm{T}}}{C_{\mathrm{T}}} \\
& \rho_{\text {chlM }}=\theta_{m}\left(\frac{\beta_{\mathrm{M}} N_{\mathrm{M}} C_{\mathrm{M}}}{\alpha_{\mathrm{chl}} I_{\mathrm{M}} a_{\mathrm{M}}}\right) \\
& \rho_{\text {chl T }}=\theta_{m}
\end{aligned}
$$

where:

$$
\beta_{\mathrm{M}}=P_{\mathrm{MAX}}\left[\frac{1}{K_{N}}\right] \exp \left[-\frac{E_{\mathrm{a}}}{R}\left(\frac{1}{T_{\mathrm{M}}}-\frac{1}{T_{\mathrm{ref}}}\right)\right]
$$

$I_{M}$ and $I_{\mathrm{T}}$ are the light levels and $T_{\mathrm{M}}$ the temperature of the layers. Eqs. (1) to (3) are then replaced by the corresponding balances of carbon, chlorophyll a and nutrient in the 2 layers:

$$
\begin{aligned}
\frac{\mathrm{d} C_{\mathrm{M}}}{\mathrm{d} t}= & \left(\beta_{\mathrm{M}} N_{\mathrm{M}}-m_{\mathrm{M}}-v / h_{\mathrm{M}}\right) C_{\mathrm{M}} \\
& +k_{2}\left(C_{\mathrm{T}}-C_{\mathrm{M}}\right) / h_{\mathrm{M}} \\
\frac{\mathrm{d} C_{\mathrm{T}}}{\mathrm{d} t}= & \alpha_{\mathrm{chl}} I_{\mathrm{T}} a_{\mathrm{T}}-m_{\mathrm{T}} C_{\mathrm{T}}-v\left(C_{\mathrm{T}}-C_{\mathrm{Y}}\right) / h_{\mathrm{T}} \\
& -k_{1} C_{\mathrm{T}} / h_{\mathrm{T}}-k_{2}\left(C_{\mathrm{T}}-C_{\mathrm{M}}\right) / h_{\mathrm{T}} \\
\frac{\mathrm{d} a_{\mathrm{M}}}{\mathrm{d} t}= & \frac{\theta_{m} \beta_{\mathrm{M}}^{2} N_{\mathrm{M}}^{2} C_{\mathrm{M}}^{2}}{\alpha_{\mathrm{chl}} I_{\mathrm{M}} a_{\mathrm{M}}}-\left(m_{\mathrm{M}}+v / h_{\mathrm{M}}\right) a_{\mathrm{M}} \\
& +k_{2}\left(a_{\top}-a_{\mathrm{M}}\right) / h_{\mathrm{M}} \\
\frac{\mathrm{d} a_{T}}{\mathrm{~d} t}= & \theta_{m} \alpha_{\mathrm{chl}} I_{\mathrm{T}} a_{\mathrm{T}}-m_{\mathrm{T}} a_{\mathrm{T}}-v\left(a_{\mathrm{T}}-a_{\mathrm{N}}\right) \cdot h_{\mathrm{T}} \\
& -k_{1} a_{\mathrm{T}} / h_{\mathrm{T}}-k_{2}\left(a_{\mathrm{T}}-a_{\mathrm{M}}\right) / h_{\mathrm{T}} \\
\frac{\mathrm{d} N_{\mathrm{M}}}{\mathrm{d} t}= & -\gamma\left(\beta_{\mathrm{M}} N_{\mathrm{M}}-\varepsilon m_{\mathrm{M}}\right) C_{\mathrm{M}} \\
& +k_{2}\left(N_{\mathrm{T}}-N_{\mathrm{M}}\right) / h_{\mathrm{M}}+A t m / h_{\mathrm{M}} \\
\frac{\mathrm{d} N_{\mathrm{T}}}{\mathrm{d} t}= & -\gamma \alpha_{\mathrm{chl}} I_{\mathrm{T}} a_{\mathrm{T}}+\varepsilon \gamma m_{\mathrm{T}} C_{\mathrm{T}} \\
& +k_{1}\left(N_{\mathrm{B}}-N_{\mathrm{T}}\right) / h_{\mathrm{T}}-k_{2}\left(N_{\mathrm{T}}-N_{\mathrm{M}}\right) / h_{\mathrm{T}}
\end{aligned}
$$

In these equations the rate of vertical diffusion is assumed to be proportional to the difference in concentration between the layers; the coefficient $k_{2}$ represents the diffusion between the mixed layer (thickness $h_{M}$ ) and the thermocline, and $k_{1}$ between the thermocline (thickness $h_{\mathrm{T}}$ ) and the deep layer. $k_{1}$ and $k_{2}$ each have the dimensions of velocity. Different loss rates $m_{M}$ and $m_{\mathrm{T}}$ have been used in the 2 layers, and a possible 
atmospheric input of nutrient to the mixed layer (Atm) has been included. These are slight generalisations of the model.

The steady-state solutions of Eqs. (14) to (19) are derived in Appendix B, some of whose properties are similar to those derived for related models in Taylor (1988). The nutrient concentration in the mixed layer, the ratio of the chlorophyll a concentration in the thermocline to that in the mixed layer, the ratio of the particulate carbon concentration in the thermocline to that of the mixed layer, and $C$ : chl $a$ in the mixed layer and the thermocline are all independent of the recycling processes and of the nutrient fluxes into the system. Any deep carbon maximum will be less pronounced than the corresponding deep chlorophyll a maximum. Increasing the light level, the initial slope of the $P-I$ curve or the prescribed upper limit of chl $a: C$, or decreasing the mortality in the thermocline will raise the thermocline chlorophyll $a$ and carbon concentrations relative to the values in the mixed layer. $C: c h l a$ will always be larger in the mixed layer than in the thermocline. The ratio of the total production in the thermocline to that in the mixed layer will be similar to the ratio of the carbon concentrations in the 2 layers.

\section{RESULTS}

Numerical simulations with the model were carried out for 5 latitudes representative of a wide range of oceanographic conditions in the North Atlantic: $0^{\circ}, 25^{\circ}$, $35^{\circ}, 47^{\circ}$ and $60^{\circ} \mathrm{N}$. The parameter values (Table 2) were chosen to be typical of these latitudes, although intermediate values were sometimes estimated by linear interpolation. The attenuation coefficient for green light was assumed to increase with latitude, consistent with variations that arise from changes in solar altitude. The change with solar angle in the pathlength of the photons per vertical metre traversed gives rise to an inverse dependence of the attenuation coefficient on the average cosine of the zenith angle (Kirk 1994). This functional dependence on latitude is similar to the variation in Table 2.

Estimates of the deep concentration of the limiting nutrient, which is expressed as nitrate in the model, were obtained from observational data (e.g Michaels et al. 1994). At $47^{\circ} \mathrm{N}$ the value was obtained from the surface nitrate concentration reached during the winter. The model always predicts depletion of the surface nutrient during the summer, and this depletion determines the size of the spring bloom. The model output differs from observations by predicting depletion of surface nutrients at $60^{\circ} \mathrm{N}$ in the Atlantic, where silicate, or some other nutrient may be consumed before nitrate becomes depleted (e.g Taylor et al. 1993). It was necessary to set the deep nitrate concentration at $60^{\circ} \mathrm{N}$ to a value which is lower than is observed in order to constrain the spring bloom to realistic values, and thus accommodate alternative limiting factors in a nitrogen-based model. The bottom concentration was set equal to the difference between the winter and summer concentrations (Taylor et al. 1991); this implies that the nitrate is standing in for some other limiting factor.

Fig. 1 shows contour plots of the annual cycles of nitrate, chlorophyll $a$ and $C$ :chl $a$ at the 5 latitudes. Each plot shows the last year of a 10 yr run, there being little difference in the annual cycles generated by the model from the second year onwards. Vertical profiles of chlorophyll a, carbon and C:chl a on Day 200 at the height of the northern hemisphere summer are shown in Fig. 2. At the equator there is little change through the year with a continuous deep chlorophyll maximum well below the mixed layer in the nutricline. This is the typical tropical structure (Herbland \& Voituriez 1979, Banse 1987). Further north there is a spring bloom at the end of the winter deep mixing, the spring bloom occurring later with increasing latitude. During the summer there is a deep chlorophyll maximum at $25^{\circ}$, $35^{\circ}$ and $47^{\circ} \mathrm{N}$ but not at $60^{\circ} \mathrm{N}$. These are the main features of the annual cycles of phytoplankton in the North Atlantic (e.g. Williams 1988, Strass \& Woods 1991, Michaels et al. 1994)

The model predicts that changes in the concentration of chlorophyll a will be accompanied by substantial vertical and temporal variations in the $C$ :chl $a$, between 25 and 50 at $60^{\circ} \mathrm{N}$ and from 25 to 160 at the equator. In general, the largest values occurred when phytoplankton abundances in the mixed layer were very low because of nutrient depletion. The ratio is reduced beneath the mixed layer during the summer due to increasing light limitation (as shown in Appen$\operatorname{dix}$ B, Eq. B10), and the sloping of the contour lines (e.g. at $47^{\circ} \mathrm{N}$ in Fig. 1) show this reduction occurs later at greater depths. The sloping contours reflect the downward transport of phytoplankton from the surface waters, especially those from the end of the spring bloom. One consequence of these variations in C: chl a is that only at the equator is the deep chlorophyll maximum accompanied by an appreciable deep carbon maximum (Fig. 2). Fig 3 shows vertical profiles of chlorophyll a and phytoplankton carbon measured by Furuya (1990) along $154^{\circ}$ to $164^{\circ} \mathrm{E}$. As in Fig. 2, there is a deep chlorophyll a maximum at $24^{\circ} \mathrm{N}$ accompanied by a much weaker deep carbon maximum, while at the equator both peaks are equally strong. Blanchot \& Rodier (1996) have observed that at the equator in the Pacific the subsurface chlorophyll maximum was at the depth of maximum picoeukaryote abundance and also at the depth of the phytoplankton carbon maximum. 
Nitrate
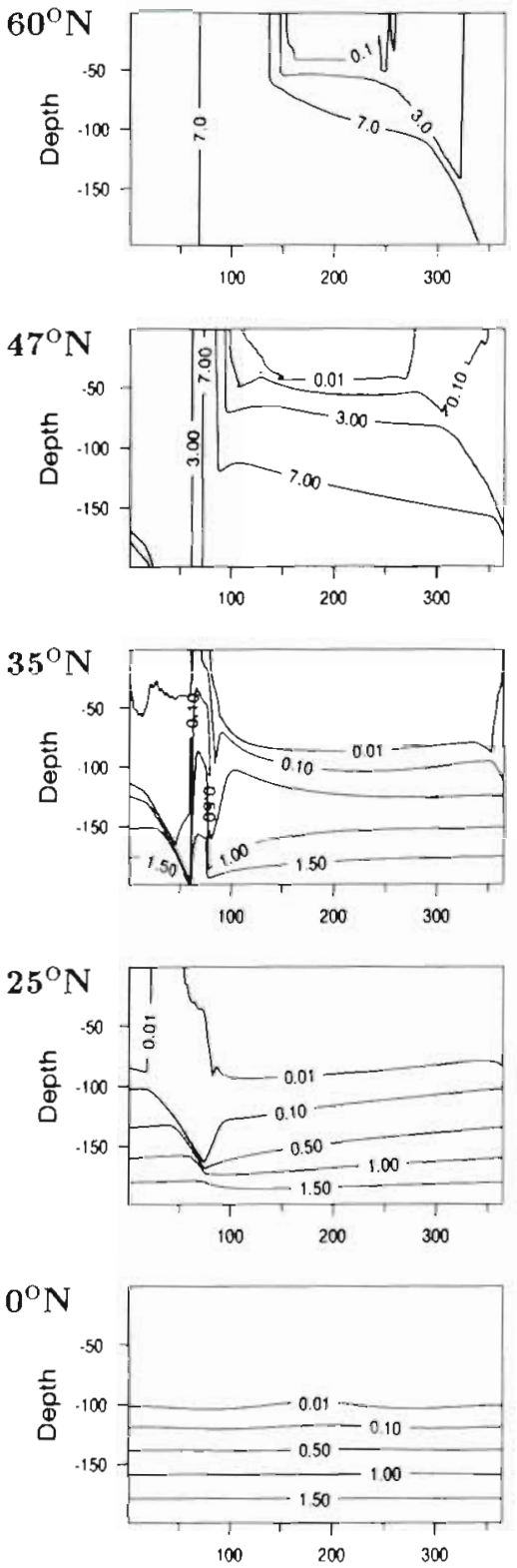

Chlorophyll
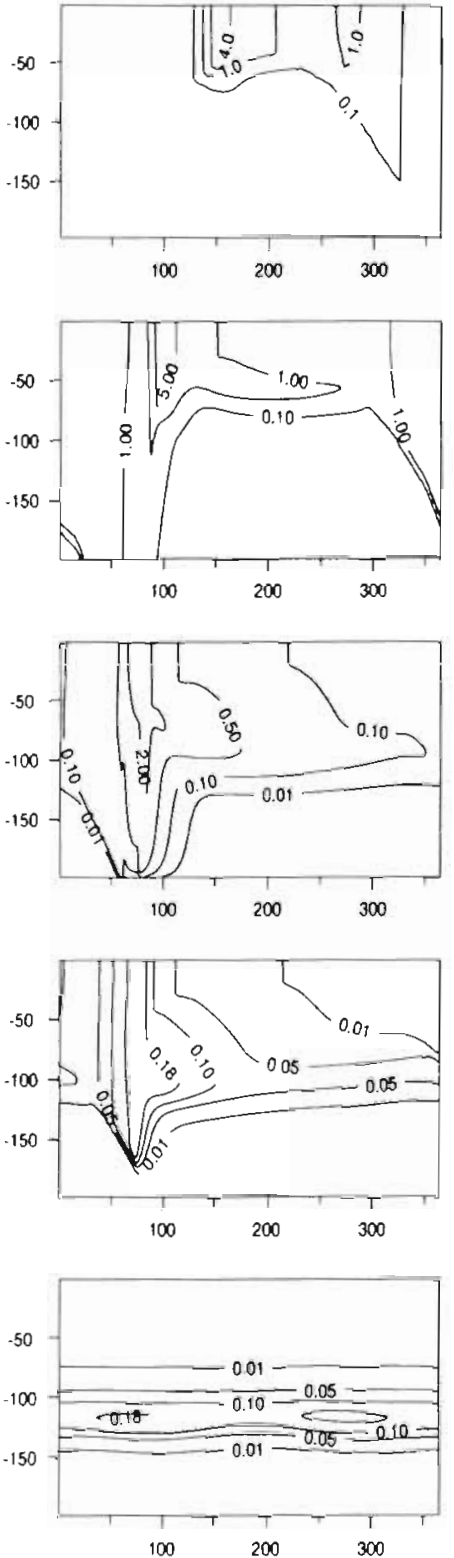

Days
Carbon:Chlorophyll
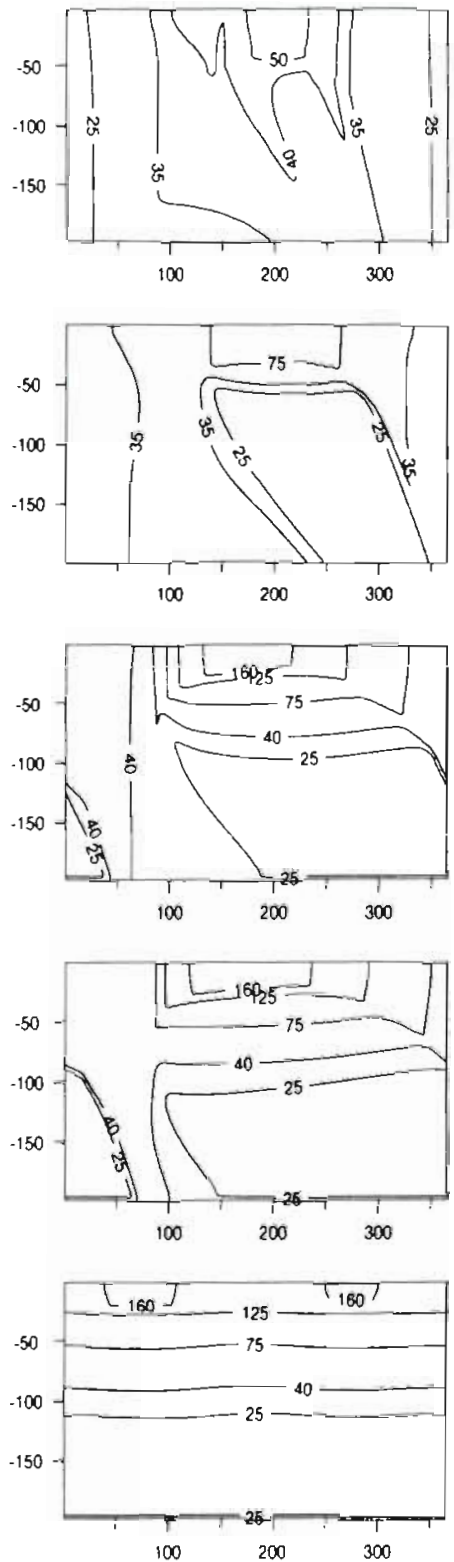

Fig. 1. Contours of dissolved nitrate $\left(\mathrm{mmol} \mathrm{m}^{-3}\right)$, chlorophyll a $\left(\mathrm{mg} \mathrm{m}^{-3}\right)$ and $\mathrm{C}$ : chl a ratio as a function of depth and time at $0^{\circ}$, $25^{\circ}, 35^{\circ}, 47^{\circ}$ and $60^{\circ} \mathrm{N}$ from the model. The parameter values used are given in Tables $1 \& 2$

In a recent study, Buck et al. (1996) measured autotrophic carbon:chlorophyll ratios in surface samples along a transit from $5^{\circ} \mathrm{S}$ to $61^{\circ} \mathrm{N}$ close to $20^{\circ} \mathrm{W}$ during July to August 1993 and related these to surface chlorophyll a concentrations. Lowest values of $C$ : chl a were observed at highest chlorophyll a concentrations. The model produces surface values that follow a similar trend to these data (Fig. 4). High values of $\mathrm{C}$ : chl $\mathrm{a}$ and low val- ues of chlorophyll a are predicted for low latitudes; chlorophyll a concentrations increase and $\mathrm{C}$ : chl a decreases, as latitude increases. Vertical variation of the C:chl a ratio was measured by Campbell et al. (1994) between October and April at station ALOHA in the North Pacific. Fig. 5 shows that the range of values predicted by the model for the same seasons at $25^{\circ} \mathrm{N}$ compares favourably with the observed range. 
Chlorophyll
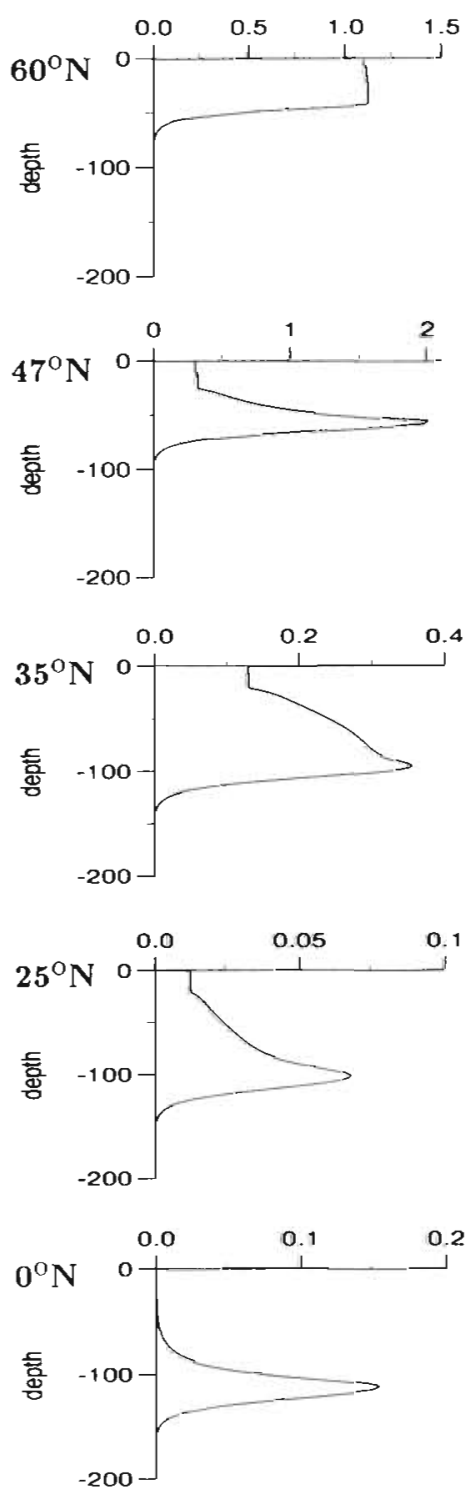

Carbon
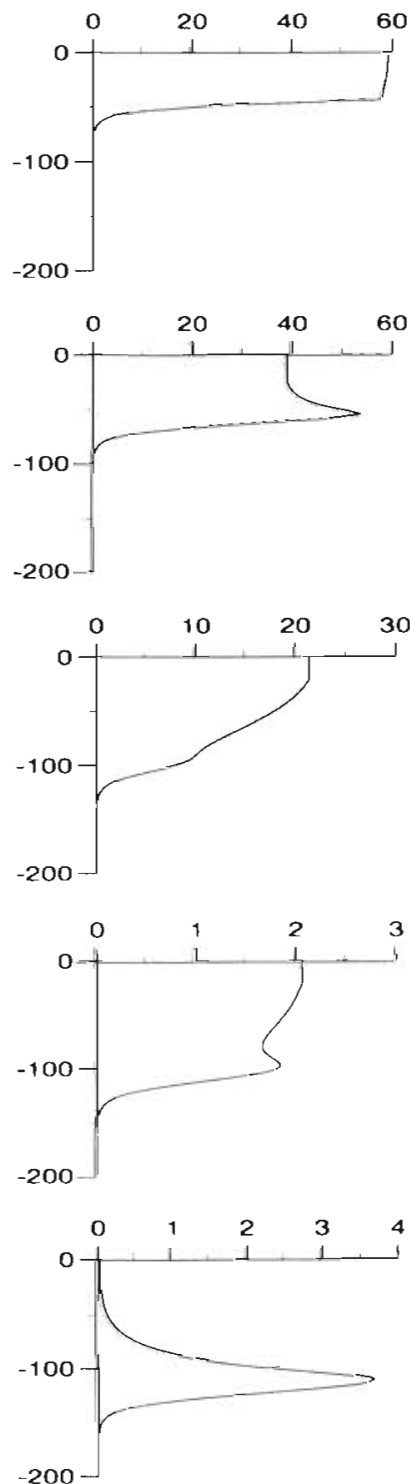

Carbon:Chlorophyll
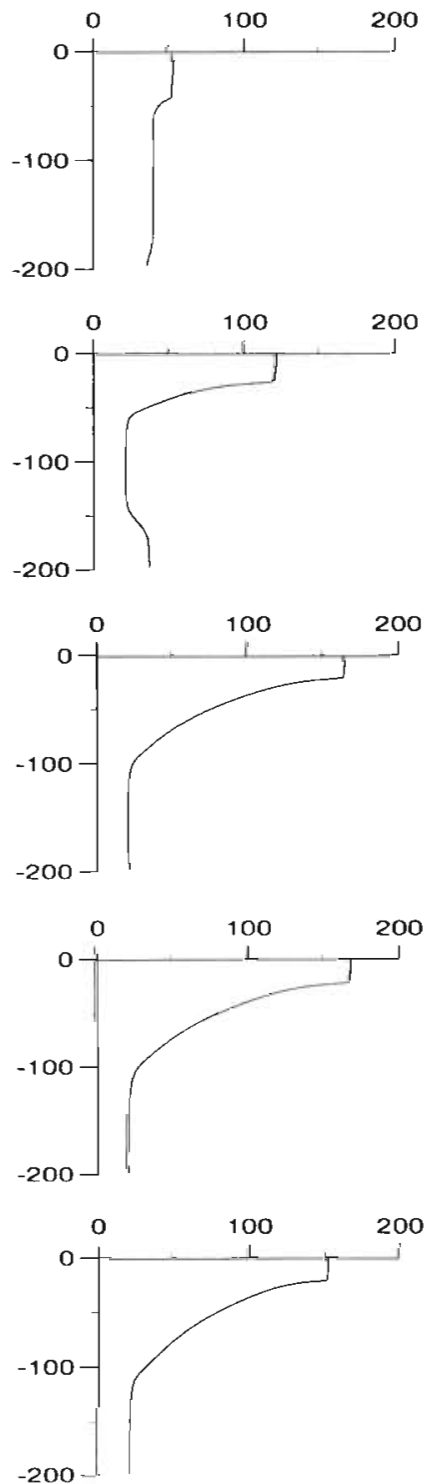

Fig. 2. Vertical profiles of chlorophyll a $\left(\mathrm{mg} \mathrm{m}^{-3}\right)$, particulate carbon $\left(\mathrm{mg} \mathrm{m}^{-3}\right)$ and $\mathrm{C}$ : chl a ratio at $0^{\circ}, 25^{\circ}, 35^{\circ}, 47^{\circ}$ and $60^{\circ} \mathrm{N}_{0}$ Day 200 of the last year of a 10 yr run of the model

\section{SENSITIVITY EXPERIMENTS}

The simulations carried out for different latitudes illustrate many aspects of the model's response to changes in the physical forcing parameters. The timing of the spring bloom is strongly affected by the light attenuation coefficient and the depth of the mixed layer because the population is light limited at this time. For the same reason, decreasing the attenuation coefficient or the mixed-layer depth raises the chlorophyll $a$ and carbon concentrations in the thermocline at the expense of those in the mixed layer
(Appendix B, Eq. B8). The greater delay of the spring bloom and the reduction of the deep chlorophyll a maximum at higher latitudes (Figs. 1 \& 2) reflect these responses.

In this section, the sensitivity of the results to other features of the model will be explored. Figs. $6 \& 7$ show the dependence of the results on our treatment of physiological acclimation of $\mathrm{C}$ :chl $a$. These figures compare simulations in which $\mathrm{C}: \mathrm{chl}$ a was either allowed to vary or kept at a fixed value of 40 throughout. With variable $\mathrm{C}: \mathrm{chl}$ a growth occurs further into the light-limited regimes, i.e. at greater depths (Fig. 6), 


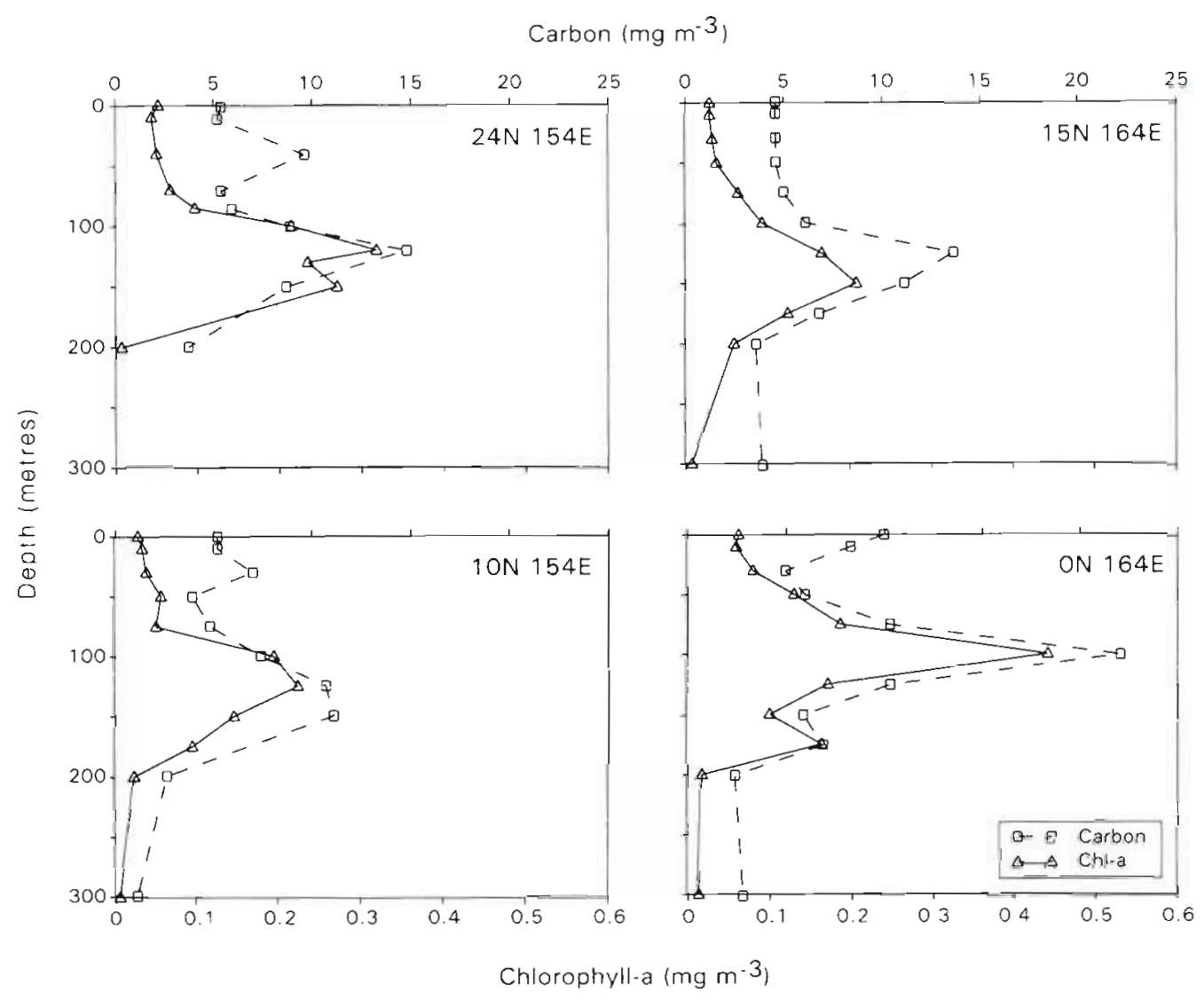

Fig. 3. Vertical distmbutions of chlorophyll a $\left(\mathrm{mg} \mathrm{m}^{-3}\right)$ and phytoplankton carbon ( $\mathrm{mg} \mathrm{m}^{-3}$ ) measured by Furuya (1990) at 4 sites in the western tropical and subtropical Pacific Ocean in early September $1979\left(10^{\circ} \mathrm{N}\right)$ and early November $1979\left(0^{\circ}, 15^{\circ}\right.$ and $\left.24^{\circ} \mathrm{N}\right)$

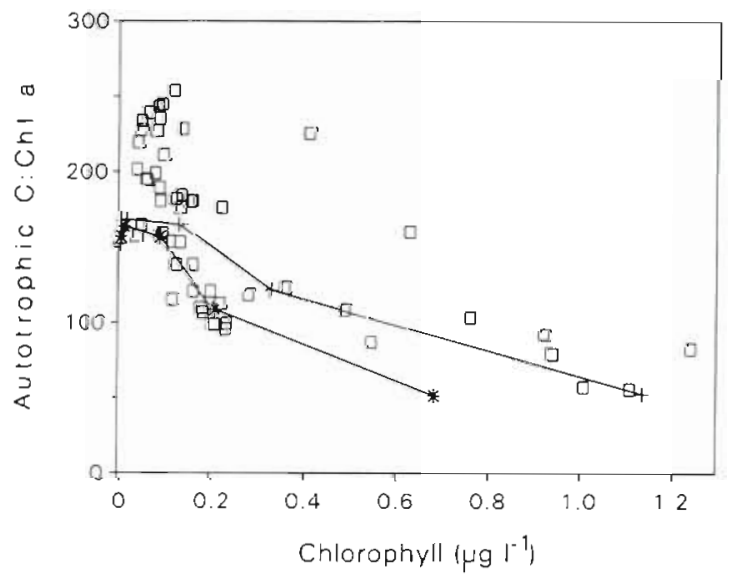

Fig. 4. Scatter plot of the relation between surface autotrophic $C: c h l a$ ratio and surface chlorophyll a along a north-south transect in the North Atlantic. The data points ( 0 ; from Buck et a. 1996) show the ratio of phytoplankton carbon, derived from a combination of flow cytometry and epifluorescence microscopy, to chlorophyll for data from $5^{\circ} \mathrm{S}$ to $61^{\circ} \mathrm{N}$ during July to August 1993. The lines connect surface values from the model at $0^{\circ}, 25^{\circ}, 35^{\circ}, 47^{\circ}$ and $60^{\circ} \mathrm{N}$ on Day 200 (*: middle of July) and Day 230 ( + : middle of August) and earlier in the spring and later in the autumn (Fig. 7). The carbon concentrations differ only modestly in these comparisons but deep chlorophyll a maxima are much more pronounced when C:chl a is allowed to vary (Fig. 6). Pronounced deep chlorophyll a maxima are typically observed in nature (Cullen 1982).

In all the calculations that have been described the sinking speed of the phytoplankton has been set to 0 . Sinking rates are known to vary considerably through the season and with latitude as the phytoplankton populations change. When calculations were also carried out with a constant sinking speed of $1 \mathrm{~m} \mathrm{~d}^{-1}$ the results differed only slightly from those presented here. At the end of the spring bloom sedimentation may be very fast which would terminate the bloom more rapidly than shown here. This faster sedimentation would also tend to steepen the sloping $C$ :chl a contours beneath the summer mixed layer in Fig. 1.

The results of the model are particularly sensitive to 2 of the parameters used: the assumed upper limit for the 


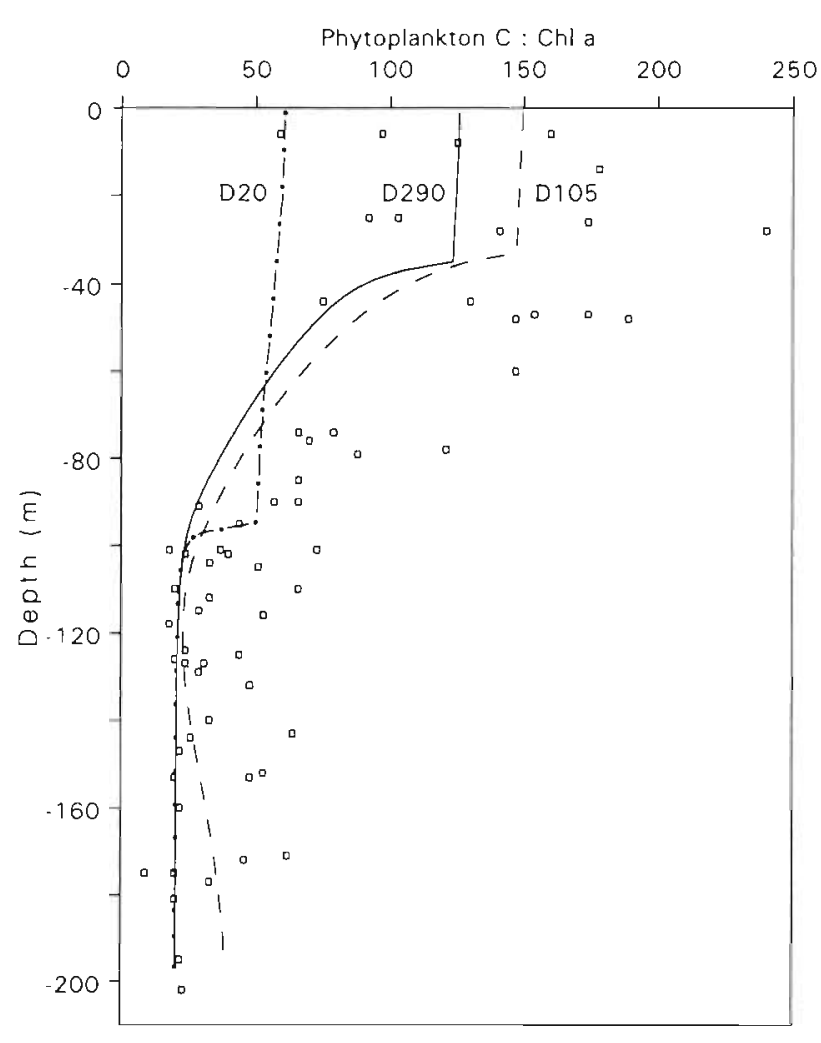

Fig. 5. Ratio of phytoplankton carbon to chlorophyll a vs depth (o) from cruises at station ALOHA in the North Pacific $\left(22^{\circ} 45^{\prime} \mathrm{N}, 158^{\circ} \mathrm{W}\right)$ during October 1991 , and between December 1991 and April 1992 (Campbell et al. 1994). The solid lines show profiles at $25^{\circ} \mathrm{N}$ from the model for Day 20 (mid-January), Day 105 (mid-April) and Day 290 (mid-October)

chlorophyll: carbon ratio $\left(\theta_{m}\right)$ and the value of the mortality rate in the summer (Fig. 8). Raising $\theta_{m}$ or lowering the mortality increases the chlorophyll $a$ and carbon concentrations and, as predicted by the steady-state analysis, gives rise to a more intense maximum at depth, especially in the chlorophyll a profile. The predicted summer values of $\mathrm{C}: \mathrm{chl}$ a decline as each of these values is increased (this can also be shown from Eqs. B11 \& B12 in Appendix B). The sign of the response to $\theta_{m}$ is not surprising, as $\theta_{m}$ sets the lower limit on the $C: c h l$ a ratio and so higher values of $\theta_{m}$ are expected to lead to lower $\mathrm{C}$ : $\mathrm{chl}$ a. It is more surprising that the model predicts that the chl a: C ratio follows the variations in $\theta_{m}$ even when chl $a: C$ is well away from $\theta_{m}$. The response of summer maximum values of $\mathrm{C}$ :chl a to mortality arises from the vertical balance of the phytoplankton growth and losses in the quasi-steady-state conditions.

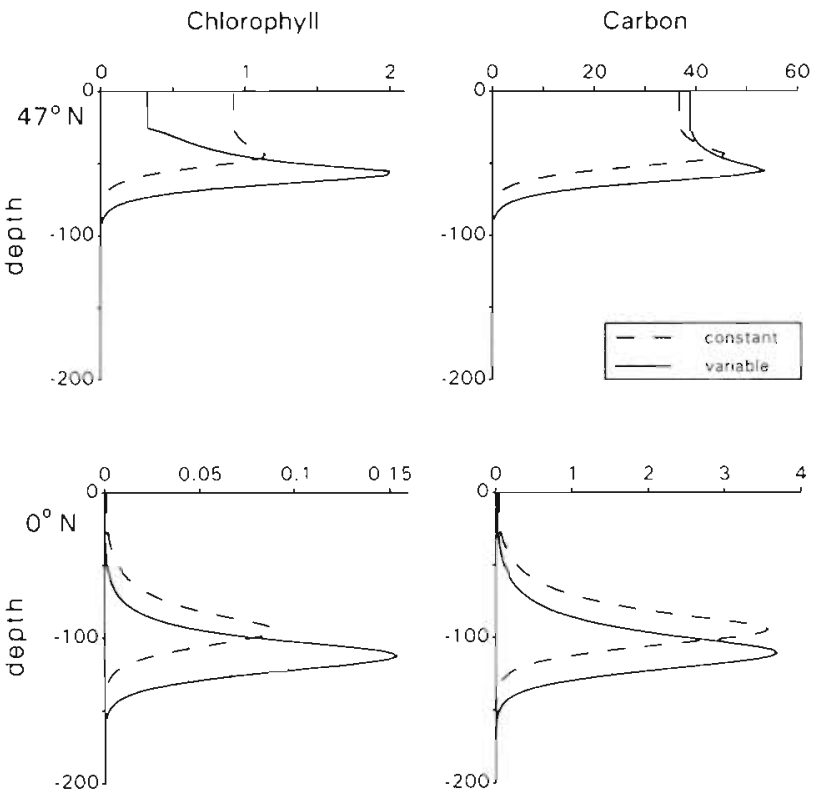

Fig. 6. Vertical profiles of chlorophyll and carbon concentrations $\left(\mathrm{mg} \mathrm{m}^{-3}\right.$ ) on Day 200 at $0^{\circ}$ and $47^{\circ} \mathrm{N}$. The solid lines show results from the calculations for Figs. 1 \& 2 , while the dotted lines show those when the carbon:chlorophyll ratio was held at a constant value of 40

\section{DISCUSSION}

\section{Model structure}

Our intention was to examine the implications of the processes affecting chlorophyll a concentrations in phytoplankton cells for the variation of $\mathrm{C}: \mathrm{chl} a$ in a range of ocean environments. To this end, the physical structure of the model was kept as simple as possible by representing the stratification in terms of a
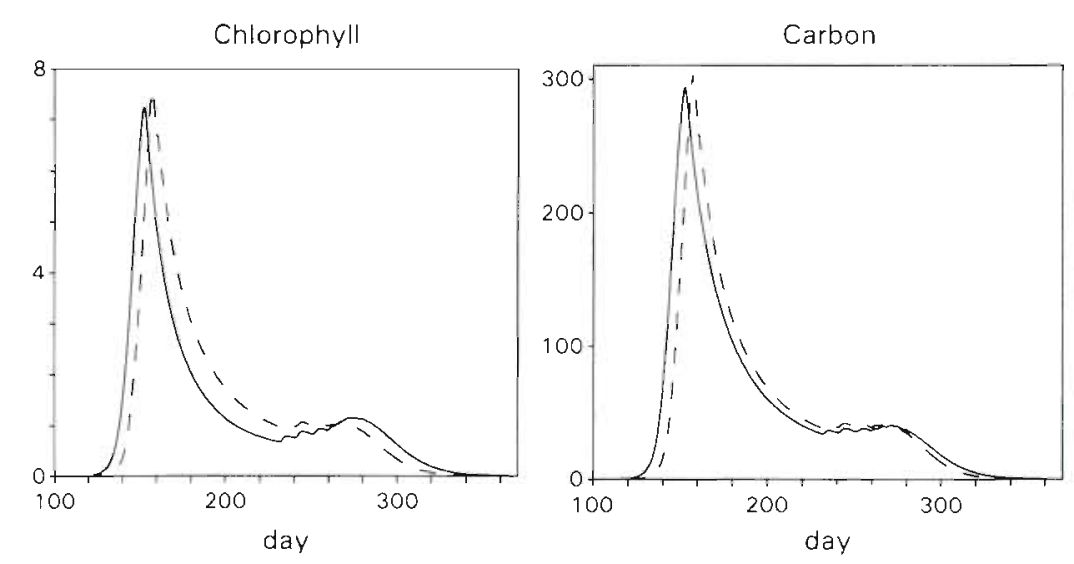

Fig. 7. Annual cycles of chlorophyll and carbon concentrations $\left(\mathrm{mg} \mathrm{m}^{-3}\right)$ in the mixed layer at $60^{\circ} \mathrm{N}$. The solid lines show results from the calculations for Figs. $1 \& 2$, while the dotted lines show those when the carbon: chlorophyll ratio was held at a constant value of 40 


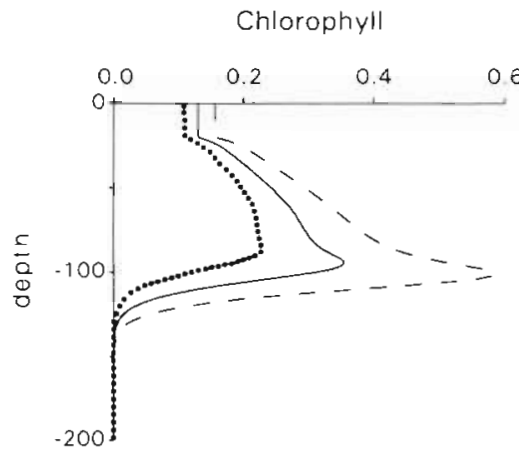

$35^{\circ} \mathrm{N}$

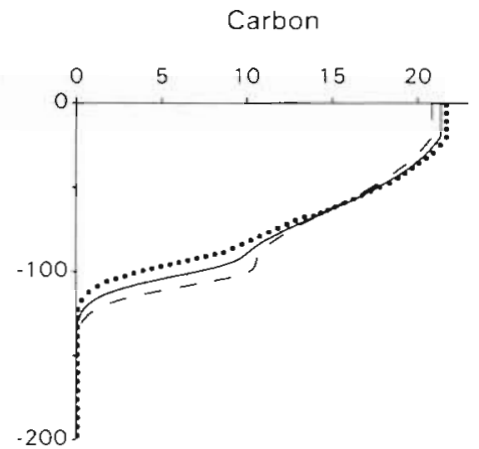

Varying Minimum C:Chl

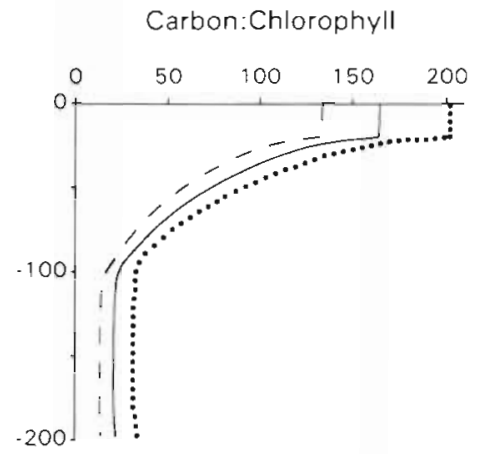

$-2001.13$

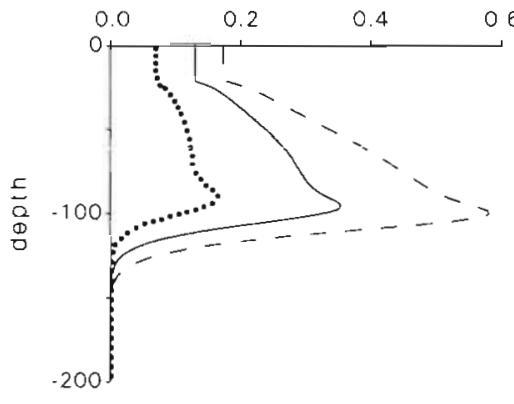

$35^{\circ} \mathrm{N}$

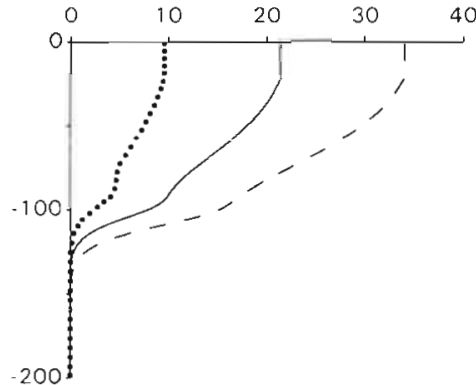

Varying Mortality

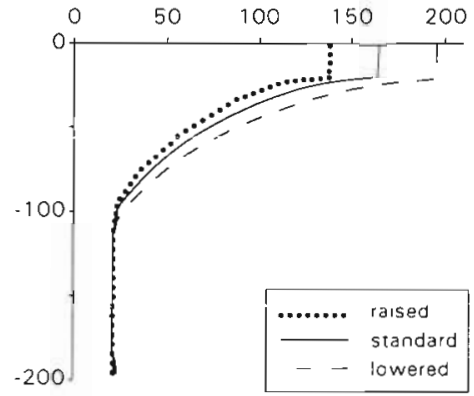

Fig. 8. Effects of varying the assumed upper limit for the chlorophyll: carbon ratio $\left(\theta_{m}\right)$ and the peak summer mortality on the vertical profiles of chlorophyll $\left(\mathrm{mg} \mathrm{m}^{-3}\right)$, carbon $\left(\mathrm{mg} \mathrm{m}^{-3}\right)$ and carbon: chlorophyll ratio at $35^{\circ} \mathrm{N}$ on Day 200 . The broken line shows the effects of lowering the parameter by $33 \%$, and the dotted line the effects of raising the parameter by $50 \%$

1-dimensional set of diffusion coefficients. We did not attempt to accurately simulate specific sites or to deal with upwelling systems. This structure appears to capture the major features of the seasonal and meridional variations. A more realistic treatment of the physical processes is to predict the vertical structure from the meteorological forcing by means of a mixed-layer model (e.g. Tett et al. 1986, Marra \& Ho 1993). Unfortunately, the biological system is sensitive to the deficiencies in these physical models which leads to little improvement in the results and would obscure the interpretation of the biological effects.

\section{Comparison of predicted biomass with observations}

The model qualitatively predicts the seasonal cycles of chlorophyll $a$ and nitrate at all latitudes. Quantitatively, the model appears to overestimate the size of the spring bloom at $35^{\circ}, 47^{\circ}$ and $60^{\circ} \mathrm{N}$, and to underestimate mixed-layer chlorophyll concentrations at $0^{\circ}$ and $20^{\circ} \mathrm{N}$ At $35^{\circ} \mathrm{N}$ the model predicts a peak chlorophyll a concentration of $2 \mathrm{mg} \mathrm{m}^{-3}$ whereas observed values at Bermuda rarely exceed $0.5 \mathrm{mg} \mathrm{m}^{-3}$ (Michaels et al. 1994). At $60^{\circ} \mathrm{N}$, the model estimates a spring bloom peak of $9 \mathrm{mg} \mathrm{m}^{-3}$, whereas observed values reach at most $4 \mathrm{mg} \mathrm{m}^{-3}$ (e.g. Williams \& Robinson 1973 , Williams \& Hopkins 1976). Part of this discrepancy may be attributable to the discrete observational data set missing the actual phytoplankton peak. The observations at $35^{\circ} \mathrm{N}$ are limited to monthly samples, whereas spring bloom chlorophyll a values considerably greater than $0.5 \mathrm{mg} \mathrm{m}^{-3}$ are predicted by the model to persist for periods much less than a month. Fig. 1 shows that $C$ chl a does not change markedly until the spring bloom is over (at $60^{\circ} \mathrm{N}$ the complete annual variation is not very large) and so it is likely that overestimates of the bloom height will not lead to significant errors in the predicted ratios. This is borne out by the $\mathrm{C}: \mathrm{chl} a$ ratio being close to 40 during each of the spring blooms in Fig. 1.

At $60^{\circ} \mathrm{N}$ a nutrient constraint was applied to allow for the high levels of nitrate persisting through the summer. Based on data from 1989, Taylor et al. (1993) have argued that this persistence is atributable to the seasonal succession, being due to silicate limitation of diatoms, grazer limitation of phytoflagellates and the slow growth of dinoflagellates. In the present model 
the summer populations at $60^{\circ} \mathrm{N}$ are nutrient limited and so may have a $\mathrm{C}$ : chl a ratio that may be too high.

Although the summer concentrations of chlorophyll a predicted by the model at $35^{\circ}, 47^{\circ}$ and $60^{\circ} \mathrm{N}$ are similar to those observed, the values of particulate carbon and chlorophyll in tropical and subtropical surface waters $10^{\circ}$ and $\left.20^{\circ} \mathrm{N}\right)$ are unrealistically low. This may have arisen because we have neglected several potentially important sources of nitrogen input to the euphotic zone in these regions. These include: nitrogen transport by vertically migrating diatom mats which may account for $50 \%$ of new production in the surface waters of the North Pacific gyre at $31^{\circ} \mathrm{N}$ (Villareal et al. 1993); nitrogen fixation by Trichodesmium spp. which has been calculated to provide at least $27 \%$ of new production at station ALOHA $\left(22^{\circ} \mathrm{N}\right.$ ) (Letelier \& Karl 1996), and atmospheric deposition of organic and inorganic nitrogen which may be important in stimulating primary production in oligotrophic ocean regions (Owens et al. 1992). Note that the steady-state analysis in Appendix $B$ shows that increasing the nutrient input to either layer will raise the biomass (and production) in each layer by the same proportion without affecting the relative intensity of either the deep chlorophyll or the deep carbon maximum and will not change $C$ : chl a values.

\section{Comparison of predicted $\mathrm{C}: \mathrm{chl}$ a with observations}

We predict an 8 -fold range in $\mathrm{C}$ : chl a from 20 to $>160 \mathrm{~g} \mathrm{~g}^{-1}$ with time, depth and latitude through the seasonal cycle. High values are predicted for the surface mixed layer under high-light/low-nutrient conditions in summer and low values are predicted for the subsurface chlorophyll a maximum layer in summer. Interestingly, intermediate values are predicted for the mixed layer in winter. Are the extreme values predicted by the model consistent with observations? Unfortunately, there is no completely unambiguous method of estimating the $\mathrm{C}$ : chl a of natural marine phytoplankton populations. Direct comparisons of particulate organic carbon with chlorophyll a cannot be made because phytoplankton are a variable, often small, proportion of total particulate organic carbon (Li et al. 1992, Campbell et al. 1994). It is necessary to differentiate the contribution of phytoplankton from the contributions of microzooplankton, bacterioplankton and detritus. Flow cytometry offers one technique for enumerating phytoplankton, including the picoplankton which are often overlooked in traditional light microscopy. By combining flow cytometric observations of abundance with literature values of cell carbon contents, Campbell and co-workers have been able to estimate the phytoplankton carbon concentration for comparison with measurements of extracted chloro- phyll. General agreement of model predictions of C:chl a with Campbell's observations was found (Figs. 4 \& 5). If anything, the model predicts $C$ : chl $a$ on the low end of the observed range.

Using the same approach as Campbell and co-workers, Li et al. (1992) had earlier found somewhat lower values of $C: c h l a$ in the Sargasso Sea $\left(36^{\circ} N\right)$ in September 1988. They calculated $\mathrm{C}: \mathrm{chl}$ a of $15 \mathrm{~g} \mathrm{~g}^{-1}$ for the nitrate-rich maximum-chlorophyll layer and $44 \mathrm{~g} \mathrm{~g}^{-1}$ for the nitrate-depleted surface mixed layer. It is likely that prochlorophytes were underestimated in the samples from the surface mixed layer because of the very low fluorescence of high-light/low-nutrient-adapted cells. It is interesting that both Li et al. (1992) and Campbell et al. (1994) report a factor of 3 difference between mean values of $\mathrm{C}$ : chl a between the surface mixed layer and the deep chlorophyll maximum layer As C: chl $a$ in the mixed layer is about 6 times the prescribed minimum value, the steady-state analysis (Eq. B10) predicts this ratio will be approximately determined by:

$$
\left(1-\frac{\theta_{m} \alpha_{c h l} I_{\mathrm{T}}}{m_{\mathrm{T}}+\left(v+k_{1}+k_{2}\right) / h_{\mathrm{T}}}\right)^{-1}
$$

and so will increase if the light level increases (e.g. at lower latitudes) or if either the prescribed minimum $C$ : chl $a$ or the initial slope of the $P-I$ curve is raised. Increasing the mortality in the thermocline will reduce this ratio.

Phytoplankton carbon concentrations estimated from cell counts should be applied with caution because of wide variations in the ratio of organic carbon to cell volume. For example the carbon:volume ratio varied from 0.04 to $0.4 \mathrm{pg} \mathrm{C} \mathrm{fl}{ }^{-1}$ in nanoplankton examined by Montagnes et al. (1994). Two-fold variations of carbon:volume with time of day have been reported for Synechococcus sp. (Stramski et al. 1995) and Thalassiosira pseudonana (Stramski \& Reynolds 1993).

Another technique for estimating $\mathrm{C}$ : chl a of phytoplankton is the ${ }^{14} \mathrm{C}$-pigment labelling technique introduced by Redalje \& Laws (1981). Using a ${ }^{14} \mathrm{C}$-labelling technique, Gieskes \& Kraay (1989) estimated C:chl a of 66 to $51 \mathrm{~g} \mathrm{~g}^{-1}$ for Indonesian surface water samples incubated at $30 \%$ of incident irradiance. C:chl a was independent of chlorophyll concentration (chlorophyll a ranged from 0.29 to $2.6 \mathrm{\mu g} \mathrm{\textrm {g } ^ { - 1 }}$ ). Phytoplankton carbon:total particulate carbon ranged from 0.24 to 2.36 (only 1 value was significantly $>1$ ).

Using a ${ }^{14} \mathrm{C}$-labelling technique, Welschmeyer \& Lorenzen (1984) measured C:chl a ratios of 19 to $150 \mathrm{~g}$ $\mathrm{g}^{-1}$ for phytoplankton from Dabob Bay, Washington. This is similar to the range predicted by the model. Welschmeyer \& Lorenzen (1984) observed pronounced vertical variability with maximum values at the surface and minimum values at depth as expected due to accli- 
mation to the vertical light gradient. Significantly, $C$ :chl a increased during the incubation, suggesting that the results of labelling experiments do not always mimic conditions in situ. Relatively high values (50 to $80 \mathrm{~g} \mathrm{~g}^{-1}$ ) of $\mathrm{C}$ : chl a were observed in winter (February). Low values (about $20 \mathrm{~g} \mathrm{~g}^{-1}$ ) were measured deep in the water column in March. The highest value was observed at the surface in August when irradiance was greatest. Our model predicts a seasonal pattern of $C$ : chl a that is broadly consistent with the observations of Welschmeyer \& Lorenzen (1984).

Taken together, the data from ${ }^{14} \mathrm{C}$ labelling and flow cytometry are consistent with variability of $C:$ chl $a$ of about a factor of 10 .

\section{Sensitivity of $\mathrm{C}: \mathrm{chl}$ a to grazing pressure}

The maximum C:chl a predicted for summer depends critically on the mortality coefficient. This is expected if the surface mixed layer in summer approximates a chemostat culture. Recall that we have treated mortality as a phytoplankton biomass specific rate. Since vertical transport of nutrients into the euphotic zone is limited by the stability of the water column, phytoplankton rely on recycled nutrients for growth in summer. Under these conditions, the rate at which nutrients are supplied to phytoplankton depends on the rate of remineralisation of nutrients by zooplankton which in turn depends on the rate at which zooplankton feed. We anticipate that the surface mixed layer evolves to a situation where the nutrient concentration equilibrates at a value that it is just sufficient to allow a growth rate which matches the mortality rate. All other factors being equal, $\mathrm{C}$ : chl $a$ is inversely related to phytoplankton growth rate under nutrient-limiting conditions (Goldman 1980, Geider et al. 1997). The process of remineralisation determines the dynamics by which the steady-state occurs. However, the analysis in Appendix $B$ shows that at the final equilibrium $C$ : chl $a$ is determined solely by the vertical balances of carbon and chlorophyll $a$ and so is independent of the recycling processes. Although their ratio does not depend on the recycling, the abundances of carbon and chlorophyll a each increase with the efficiency of recycling. The dependence of $C$ : chl a on mortality points to an important interaction between ecological processes such as grazing and the physiological processes that regulate phytoplankton pigment content.

\section{Timing of the spring bloom}

Fig. 7 shows that lowering of the $\mathrm{C}$ : chl a ratio allows the spring bloom to occur almost a week earlier than when the ratio was held at 40 . At the time of the bloom the ratio is not less than 40 so that this difference must originate in the very early stages of the bloom development. Both the magnitude of the spring bloom and the summer concentration of chlorophyll in the deep chlorophyll maximum depend on the entrainment of nitrate into the surface mixed layer in winter. Therefore, carry-over from winter is an important process in the model and winter conditions could be a significant source of interannual variations.

\section{Is the deep chlorophyll a maximum a deep carbon maximum?}

In the model calculations, deep chlorophyll a maxima were only accompanied by appreciable deep carbon maxima at the equator, and the steady-state analysis in Appendix $B$ shows that deep chlorophyll a maxima will be more pronounced than deep carbon maxima. This is in agreement with Cullen (1982) who pointed out that, because the relationship between chlorophyll a and phytoplankton biomass is highiy variable, vertical profiles of chlorophyll a must be interpreted with caution if their ecological significance is to be established. Kiefer \& Kremer (1981) have constructed a chlorophyll-nitrogen model in which the chlorophyll concentration per cell is proportional to the specific growth rate of the cells and inversely proportional to the light level. Simulations of Station $\mathrm{S}$ in the Sargasso Sea using this model gave deep chlorophyll maxima without deep maxima of phytoplankton nitrogen

\section{Implications for validating pelagic ecosystem models}

Our results have significant implications for validation of pelagic ecosystem models using chlorophyll a as a measure of phytoplankton biomass. We have already shown that vertical variation of chlorophyll concentration within the euphotic zone does not necessarily correspond to a variation of phytoplankton biomass. Models which equate chlorophyll a to phytoplankton carbon or nitrogen are likely to misrepresent the processes responsible for formation of the deep chlorophyll maximum layer.

The seasonal variability of $\mathrm{C}$ : chl a by a factor of 3 to 4 predicted for $35^{\circ} \mathrm{N}$ is significant when compared with the annual range of chlorophyll a concentrations of about a factor of 10 to 20 at the Bermuda JGOFS time series station. In contrast, the variations of $\mathrm{C}: \mathrm{chl}$ a between about 20 to $40 \mathrm{~g} \mathrm{~g}^{-1}$ predicted for $60^{\circ} \mathrm{N}$ are minor when compared with the much larger seasonal range of chlorophyll $a$ at this latitude. Conventional 
models will be least subject to errors associated with incorrect parameterisation of $\mathrm{C}$ :chl a or $\mathrm{N}$ :chl $a$ in such high latitude waters. These are the regions with the largest rates of biological sequestration of $\mathrm{CO}_{2}$ by export of organic matter to intermediate and bottom waters and the sediments, but lower latitudes where the sensitivity to variable $C$ :chl $a$ is higher cover a much larger ocean area.

\section{Implications for estimating the consumption of inorganic carbon}

The model assumes a constant carbon-to-nitrogen ratio $(C: N)$. Since phytoplankton production is ultimately limited by nitrogen uptake in the model simulations, the draw-down of dissolved inorganic carbon $\left(\mathrm{TCO}_{2}\right)$ will not be greatly affected by the predicted acclimation of $\mathrm{C}$ : chl a. A slight increase of $\mathrm{TCO}_{2}$ drawdown arises by allowing the phytoplankton to acclimate to low light by decreasing $C$ :chl a. This in turn leads to net growth of phytoplankton at slightly greater depths in stably stratified waters, and thus draw-down of $\mathrm{TCO}_{2}$ over a slightly greater depth range than would be the case if $C$ : chl a were assumed to be constant at a value of $40 \mathrm{~g} \mathrm{~g}^{-1}$.

Acknowledgements. We thank John Stephens for his assistance with the processing of the data and the preparation of the figures. This work was supported by the UK Natural Environment Research Council as part of Strategic Research Project 1 of the Plymouth Marine Laboratory and PRIME (Planktonic Reactivity in the Marine Environment) (A.H.T.), under Testable Models of Aquatic Ecosystems Special Topic GST/02/1167 (A.H.T.) and NERC under grant GR3/10222 (R.J.G.). It was also supported by the US Department of Energy under grant DE-FG02-93ER6195 (R.J.G.). This is PRIME contribution 36.

Appendix A. Finite-difference equations

If the values of $C(z, t), a(z, t)$ and $N(z, t)$ are defined on a vertical grid of $J$ points from $j=1,2, \ldots, J$ with spacing $\Delta z$, Eqs. (1) to (4) can be approximated by finite-difference equations using the Crank-Nicholson scheme as in Taylor et al. (1986):

$$
\begin{aligned}
& \frac{N_{j}^{n+1}-N_{j}^{n}}{\Delta t}= \\
& -\frac{\gamma g_{j}^{n} N_{j}^{n+1} C_{j}^{n}}{N_{j}^{n}+K_{N}}+\gamma \varepsilon m^{n} C_{j}^{n}+\frac{\left[K_{j+1 / 2}^{n}\left(N_{i+1}^{n+1}-N_{j}^{n+1}\right)-K_{j-1 / 2}^{n}\left(N_{j}^{n+1}-N_{j+1}^{n+1}\right)\right]}{2 \Delta z^{2}}+\frac{\left[K_{j+1 / 2}^{n}\left(N_{j+1}^{n}-N_{j}^{n}\right)-K_{j-1 / 2}^{n}\left(N_{j}^{n}-N_{j-1}^{n}\right)\right]}{2 \Delta z^{2}} \\
& \frac{C_{j}^{n+1}-C_{j}^{n}}{\Delta t}= \\
& \frac{g_{j}^{n} N_{j}^{n+1} C_{j}^{n}}{N_{j}^{n j}+K_{N}}-m^{n} C_{j}^{n}-V \frac{\left(C_{j}^{n}-C_{j-1}^{n}\right)}{\Delta z}+\frac{\left[K_{j+1 / 2}^{n}\left(C_{j+1}^{n+3}-C_{j}^{n+1}\right)-K_{j-1 / 2}^{n}\left(C_{j}^{n+1}-C_{j-1}^{n+1}\right)\right]}{2 \Delta z^{2}}+\frac{\left[K_{j+1 / 2}^{n}\left(C_{j+1}^{n}-C_{j}^{n}\right)-K_{j-1 / 2}^{n}\left(C_{j}^{n}-C_{j-1}^{n}\right)\right]}{2 \Delta z^{2}} \\
& \frac{a_{j}^{n+1}-a_{j}^{n}}{\Delta t}= \\
& \rho_{(+11}^{n} \frac{g_{j}^{n} N_{j}^{n+1} C_{j}^{n}}{N_{j}^{n}+K_{N}}-m^{n} a_{j}^{n}-V \frac{\left(a_{j}^{n}-a_{j-1}^{n}\right)}{\Delta z}+\frac{\left[K_{j+1 / 2}^{n}\left(a_{j+1}^{n+1}-a_{j}^{n+1}\right)-K_{j-1 / 2}^{n}\left(a_{j}^{n+1}-a_{j-1}^{n+1}\right)\right]}{2 \Delta z^{2}}+\frac{\left[K_{j+1 / 2}^{n}\left(a_{j+1}^{n}-a_{j}^{n}\right)-K_{j-1 / 2}^{n}\left(a_{j}^{n}-a_{j-1}^{n}\right)\right]}{2 \Delta z^{2}}
\end{aligned}
$$

where $C_{j}^{n}, a_{j}^{n}$ and $N_{j}^{n}$ are the values at the $j$ th grid-point after $n$ time-steps of length $\Delta t$. In these equations, $P_{m}^{C}(T, N)$ of Eq. (6) has been written as:

$$
P_{m}^{C}(T, N)=\frac{g N}{N+K_{N}}
$$

This allows the part of the Monod term to be written implicitly in Eqs. (A1) to (A3), which has the advantage of preventing negative nutrient values occurring when nutrients become depleted. The growth, mortality and recycling terms $\left(g g_{i}^{n} m^{n}\right.$ and $\varepsilon_{j}^{n}$ ) are calculated at the same grid-points as $C_{1}^{n}, a_{j}^{n}$ and $N_{j}^{n}$, while the diffusion coefficients $K_{j+1 / 2}^{n}$ are evaluated at points mid-way between the grid-points. At each time step, first Eq. (A1), then Eq. (A2) and finally Eq. (A3) are solved for all grid-points down the water column including the upper and lower boundary conditions. This is carried out by the tridiagonal matrix algorithm (e.g. Rıchtmyer \& Morton 1957, p. 189). 
Appendix B. Steady-state solutions

The steady-state solutions of Eqs. (14) to (19) are given by:

$$
\begin{aligned}
& \left(\beta_{M} N_{M}-A_{1}\right) C_{M}+A_{2} C_{\mathrm{T}}=0 \\
& B_{1} a_{T}+B_{2} C_{M}-B_{3} C_{T}=0 \\
& D_{1} \frac{\beta_{M}^{2} N_{M}^{2} C_{M}^{2}}{a_{M}}-A_{1} a_{M}+A_{2} a_{T}=0 \\
& B_{2} a_{M}-E_{1} a_{T}=0
\end{aligned}
$$

where:

$$
\begin{aligned}
& A_{1}=m_{\mathrm{M}_{1}}+\frac{v+k_{2}}{h_{\mathrm{M}}} \quad A_{2}=\frac{k_{2}}{h_{\mathrm{M}}} \\
& B_{1}=\alpha_{\mathrm{chl}} I_{\mathrm{T}} \quad B_{2}=\frac{v+k_{2}}{h_{\mathrm{T}}} \quad B_{3}=m_{\mathrm{T}}+\frac{v+k_{1}+k_{2}}{h_{\mathrm{T}}} \\
& D_{1}=\frac{\theta_{m}}{\alpha_{\mathrm{chl}} I_{\mathrm{M}}} . \quad E_{1}=B_{3}-\theta_{m} B_{1}=B_{3}-\theta_{m} \alpha_{c h l} I_{\mathrm{T}}
\end{aligned}
$$

From Eq. (B4):

$$
\frac{a_{M}}{a_{T}}=\frac{m_{\top}+\left(v+k_{1}+k_{2}\right) / h_{\top}-\alpha_{\text {chi }} l_{\top} \theta_{m}}{\left(v+k_{2}\right) / h_{T}}
$$

This ratio expresses the intensity of the deep chlorophyll a maximum, being small when the maximum is strong. It shows that the intensity is independent of recycling processes, fluxes of nutrients into the system, temperature and of the mortality in the mixed layer. Increasing the light level $\left(I_{T}\right)$. the initial slope of the $P$-I curve $\left(\alpha_{c h l}\right)$ or the maximum chl a:C ratio $\left(\theta_{m}\right)$ lead to a more pronounced deep chlorophyl a maximum. Increasing the mortality in the thermocline and the mixing at the bottom of the thermocline reduces the relative intensity of the deep peak

From Eq. (B2):

$$
\frac{C_{\mathrm{M}}}{C_{\mathrm{T}}}=\frac{m_{\mathrm{T}}+\left(v+k_{1}+k_{2}\right) / h_{\mathrm{T}}-\alpha_{\mathrm{chl}} I_{\mathrm{T}}\left(\mathrm{a}_{\mathrm{T}} / C_{\mathrm{T}}\right)}{\left(v+k_{2}\right) h_{\mathrm{T}}}
$$

This equation is similar to Eq. (B8) and so the intensity of any deep carbon maximum shows similar dependencies to the deep chlorophyll a maximum. There are some differencies, however. As $a_{\uparrow} / C_{\top}$ will normally be less than its maximum limit $\theta_{m}$, any deep carbon peak will be less intense than the corresponding deep chlorophyli a peak, and deep carbon values will increase less with the initial slope of the $P$-I curve than the deep chlorophyll a values. The dependence of any deep carbon peak on the light intensity will be much weaker than that of the deep chlorophyll a peak because $a_{\mathrm{T}} / C_{\mathrm{T}}$ is expected to decline as the light increases.

From Eqs. (B2), (B4) \& (B7):

$$
\frac{C_{T}}{a_{T}}=\frac{C_{M}}{a_{M}}-\frac{B_{1}}{B_{3}}\left(\theta_{m} \frac{C_{M}}{a_{M}}-1\right)
$$

As $B_{1}$ and $B_{3}$ are both positive and $\theta_{m} C_{M} / \partial_{M}$ will be greater than $1, C: c h 1$ in the thermocline will always be less than $\mathrm{C}: \mathrm{chl} a$ in the mixed layer
$\mathrm{C}: \mathrm{chl} \mathrm{a}$ in the mixed layer can be obtained from Eqs. (B1) to (B4). Using Eq. (B4), Eq. (B3) becomes:

$$
\begin{aligned}
\beta_{M} N_{M} C_{M} & =a_{M} \sqrt{\frac{1}{D_{1}}\left(A_{1}-\frac{A_{2} B_{2}}{E_{1}}\right)} \\
& =a_{T} \frac{E_{1}}{B_{2}} \sqrt{\frac{1}{D_{1}}\left(A_{1}-\frac{A_{2} B_{2}}{E_{1}}\right)}
\end{aligned}
$$

Substituting in Eq. (B1) and using Eqs. (B2) \& (B4) gives expressions for $\mathrm{C}$ : chl $a$ in the 2 layers:

$$
\begin{aligned}
& \frac{C_{M}}{a_{M}}=\frac{\frac{A_{2} B_{1} B_{2}}{E_{1}}+B_{3} \sqrt{\frac{1}{D_{1}}\left(A_{1}-\frac{A_{2} B_{2}}{E_{1}}\right)}}{A_{1} B_{3}-A_{2} B_{2}} \\
& \frac{C_{\mathrm{T}}}{a_{\mathrm{T}}}=\frac{A_{1} B_{1}+E_{1} \sqrt{\frac{1}{D_{1}}\left(A_{1}-\frac{A_{2} B_{2}}{E_{1}}\right)}}{A_{11} B_{3}-A_{2} B_{2}}
\end{aligned}
$$

Only $A_{1}$ and $B_{3}$ depend on the mortality, and only $D_{1}$ and $E_{1}$ depend on $\theta_{m}$. Eq. (B13) shows that $C_{T} / a_{T}$ decreases if either of these is increased. A similar, but less marked, sensitivity occurs in the mixed layer

Using Eq. (B1.2), $C_{M} / C_{T}$ can be calculated by means of Eq. (B9) and the nutrient concentration in the mixed layer $\left(N_{M}\right)$ can then be calculated from Eq. (B1). None of these 3 ratios therefore depend on the recycling processes or the nutrient inputs to the layers. The ratio of the production in the 2 layers can also be calculated. Dividing Eq. (B1) by Eq. (B2):

$$
\begin{aligned}
& \frac{\beta_{\mathrm{M}} N_{\mathrm{M}} C_{\mathrm{M}}}{\alpha_{\mathrm{chl}} I_{\mathrm{T}} a_{\mathrm{T}}}=\frac{A_{2}-A_{1} \frac{C_{\mathrm{M}}}{C_{\top}}}{B_{2} \frac{C_{\mathrm{M}}}{C_{T}}-B_{3}} \\
& \frac{\beta_{\mathrm{M}} N_{\mathrm{M}} C_{\mathrm{M}} h_{\mathrm{M}}}{\alpha_{\mathrm{chl}} I_{\mathrm{T}} a_{\mathrm{T}} h_{\mathrm{T}}}=\frac{\left(m_{\mathrm{M}} h_{\mathrm{M}}+v+k_{2}\right) \frac{C_{\mathrm{M}}}{C_{\mathrm{T}}}-k_{2}}{\left(m+h_{\mathrm{T}}+v+k_{1}+k_{2}\right)-\left(v+k_{2}\right) \frac{C_{\mathrm{M}}}{C_{\mathrm{T}}}}
\end{aligned}
$$

The left-hand side of this equation is the ratio of the total production in the mixed layer to that in the themocline. This ratio is independent of the recycling and of the nutrient flows into the layers. Eq. (B11) shows the ratio decreases with increasing light. When $C_{M}=C_{T}$ this ratio reduces to

$$
\frac{\beta_{\mathrm{M}} N_{\mathrm{M}} C_{\mathrm{M}} h_{\mathrm{M}}}{\alpha_{\mathrm{chl}} I_{\mathrm{T}} a_{\mathrm{T}} h_{\mathrm{T}}}=\frac{\left(m_{\mathrm{M}} h_{\mathrm{M}}+v\right)}{\left(m_{\mathrm{T}} h_{\mathrm{T}}+k_{1}\right)}
$$

which can be either greater or less than 1 depending on the right-hand parameter values. When there is a pronounced deep carbon maximum, i.e. $C_{\mathrm{M}} / C_{\mathrm{T}}$ is small, this ratio also becomes small so that production peaks in the thermocline. If the other parameters in Eq. (B14) do not vary, then the production ratio increases as $C_{M} / C_{T}$ increases. 


\section{LITERATURE CITED}

Banse K (1977) Determining the carbon-to-chlorophyll ratio of natural phytoplankton. Mar Biol 41:199-212

Banse K (1987) Clouds, deep chlorophyll maxima and the nutrient supply to the mixed layer of stratified water bodies. J Plankton Res 9:1031-1036

Blanchot J, Rodier M (1996) Picophytoplankton abundance and biomass in the western tropical Pacific Ocean during the 1992 El Niño year: results from flow cytometry. Deep Sea Res I 43:877-895

Buck KR, Chavez FP, Campbell L (1996) Basin-wide distributions of living carbon components and the inverted trophic pyramid of the central gyre of the North Atlantic Ocean, summer 1993. Aquat Microb Ecol 10:283-298

Bunker AF (1976) Computations of surface energy flux and annual air-sea interaction cycles of the North Atlantic Ocean. Mon Weather Rev 104:1122-1140

Campbell L, Nolla HA, Vaulot D (1994) The importance of Prochlorococcus to community structure in the central North Pacific Ocean. Limnol Oceanogr 39:954-961

Cloern JE, Grenz C, Vidergar-Lucas L (1995) An empirical model of the phytoplankton chlorophyll:carbon ratiothe conversion between productivity and growth. Limnol Oceanogr 7:1310-1313

Cullen JJ (1982) The deep chlorophyll maximum layer: comparing vertical profiles of chlorophyll a. Can J Fish Aquat Sci 39:791-803

Doney SC, Glover DM, Najjar RG (1996) A new coupled, onedimensional biological-physical model for the upper ocean: applications to the JGOFS Bermuda Atlantic Timeseries Study (BATS) site. Deep Sea Res 43:591-624

Eppley RW (1972) Temperature and phytoplankton growth in the sea. Fish Bull US 70:1063-1085

Falkowski PG, La Roche J (1991) Acclimation to spectral irradiance in algae. J Phycol 27:8-14

Fasham MJR, Ducklow HW. McKelvie SM (1990) A nitrogenbased model of plankton dynamics in the ocean mixed layer. J Mar Res 48:591-639

Furuya K (1990) Subsurface chlorophyll maximum in the tropical and subtropical western Pacific Ocean: vertical profiles of phytoplankton biomass and its relationship with chlorophyll a and particulate organic carbon. Mar Biol 107:529-539

Geider RJ (1987) Light and temperature dependence of the carbon to chlorophyll ratio in microalgae and cyanobacteria: implications for physiology and growth of phytoplankton. New Phytol 106:1-34

Geider RJ (1993) Quantitative phytoplankton ecophysiology: implications for primary production and phytoplankton growth. ICES Mar Sci Symp 197:52-62

Geider RJ, MacIntyre HL, Kana TM (1997) A dynamic model of phytoplankton growth and acclimation: responses of the balanced growth rate and the chlorophyll a:carbon ratio to light, nutrient-limitation and temperature. Mar Ecol Prog Ser 148:187-200

Gieskes WWC, Kraay GW (1989) Estimating the carbon-specific growth rate of the major algal species groups in eastern Indonesian waters by $14 \mathrm{C}$ labeling of taxon-specific carotenoids. Deep Sea Res 36:11127-1139

Goericke R, Welschmeyer NA (1993) The chlorophylllabelling method: measuring specific rates of chlorophyll $a$ synthesis in cultures and the open ocean. Limnol Oceanogr 38:80-95

Goldman JC (1980) Physiological processes, nutrient availability, and the concept of relative growth rate in marine phytoplankton ecology. In: Falkowski PG (ed) Pri- mary productivity in the sea. Plenum Press, New York, p $179-193$

Herbland A, Voituriez B (1979) Hydrological structure analysis for estimating the primary production in the tropical Atlantic Ocean. J Mar Res 37:87-101

Kiefer DA (1993) Modelling growth and light absorption in the marine diatom Skeletonema costatum. In: Evans GT, Fasham MJR (eds) Towards a model of ocean biogeochemical processes. Springer-Verlag, Berlin, p 91-121

Kiefer DA, Kremer JN (1981) Origins of vertical patterns of phytoplankton and nutrients in the temperate, open ocean: a stratgraphic hypothesis. Deep Sea Res 28A: $1087-1105$

Kirk JTO (1994) Light and photosynthesis in aquatic ecosystems. Cambridge University Press, Cambridge

Langdon $C$ (1988a) On the causes of interspecific differences in the growth-irradiance relationship for phytoplankton. I. A comparative study of the growth-irradiance relationship of three marine phytoplankton species: Skeletonema costatum, Olisthodiscus luteus and Gonyaulax tamarensis. J Plankton Res 10:1291-1312

Langdon C (1988b) On the causes of interspecific differences in the growth-irradiance relationship for phytoplankton. II. A general review. J Plankton Res 10:1291-1312

Letelier RM, Karl DM (1996) Role of Trichodesmium spp. in the productivity of the subtropical North Pacific Ocean. Mar Ecol Prog Ser 133:263-273

Levitus S (1982) Climatological atlas of the world ocean. NOAA Prof Pap 13, US Govt Print Off, Washington, DC

Li WKW, Dickle PM, Irwin BD, Wood AM (1992) Biomass of bacteria, cyanobacteria, prochlorophytes and photosynthetic eukaryotes in the Sargasso Sea. Deep Sea Res 39: 501-519

Longhurst A. Sathyendranath S, Platt T, Caverhill C (1995) An estimate of global primary production in the ocean from satellite radiometer data. J Plankton Res 17:1245-1271

Marra J, Ho C (1993) Initiation of the spring bloom in the northeast Atlantic $\left(47^{\circ} \mathrm{N}, 20^{\circ} \mathrm{W}\right)$ : a numencal simulation Deep Sea Res 40:55-73

Michaels AF, Knap AH, Dow RL, Gundersen K, Johnson RJ Sorensen J, Close A, Knauer GA, Lohrenz SE, Asper VA. Tuel M, Bidigare R (1994) Seasonal patterns of ocean biogeochemistry at the U.S. JGOFS Bermuda Atlantic Timeseries Study site. Deep Sea Res 41:1013-1038

Montagnes DJS, Berges JA, Harrison PJ, Taylor FRJ (1994) Estimating carbon, nitrogen, protein, and chlorophyll a from volume in marine phytoplankton. Limnol Oceanogr 39:1044-1060

Owens NJP, Galloway JN, Duce RA (1992) Episodic atmospheric nitrogen deposition to oligotrophic oceans. Nature 357:397-399

Platt T, Harrison WG (1985) Biogenic fluxes of carbon and oxygen in the ocean. Nature 318:55-58

Redalje DG, Laws EA (1981) A new method for estimating phytoplankton growth rates and carbon biomass. Mar Biol 62:73-79

Richtmyer RD, Morton KW (1957) Difference methods for initial-value problems. Interscience Publishers, New York

Stramski D, Reynolds RA (1993) Diel variations in the optical properties of a marine diatom. Limnol Oceanogr 38: $1347-1364$

Stramskı D, Shalapyonok A, Reynolds RA (1995) Optıcal characterization of the unicellular cyanobacterium Synechococcus grown under a day-night cycle in natural irradiance. J Geophys Res 100:13295-13307

Strass V, Woods JD (1991) New production in the summer revealed by the meridional slope of the deep chlorophyll 
maximum. Deep Sea Res 38:35-56

Strickland JDH (1960) Measuring the production of marine phytoplankton. Bull Fish Res Bd Can 122:1-172

Taylor A.H (1988) Characteristic properties of models for the vertical distribution of phytoplankton under stratification. Ecol Model 40:175-199

Taylor AH, Harbour DS, Harris RP, Burkill PH, Edwards ES (1993) Seasonal succession in the pelagic ecosystem of the North Atlantic and the utilization of nitrogen. J Plankton Res 15:875-891

Taylor AH, Harris JRW, Aiken J (1986) The interaction of physical and biological processes in a model of the vertical distribution of phytoplankton under stratufication. In: Nihoul JCJ (ed) Marine interfaces ecohydrodynamics. Elsevier Oceanography Series 42, Elsevier, New York, p 313-330

Taylor AH, Stephens JA (1993) Diurnal variations of convective mixing and the spring bloom of phytoplankton. Deep Sea Res 40:389-408

Taylor AH, Watson A.J, Ainsworth M, Robertson JE, Turner DR (1991) A modelling investigation of the role of phytoplankton in the balance of carbon at the surface of the North Atlantic. Global Biogeochem Cycles 5:151-171

This article was submitted to the editor
Tett PB, Edwards A, Jones K (1986) A model for the growth of shelf-sea phytoplankton in summer. Estuar Coast Shelf Sci 23:641-672

Villareal TA, Altabet MA, Culver-Rymsza K (1993) Nitrogen transport by vertically migrating diatom mats in the North Pacific Ocean. Nature 363:709-712

Welschmeyer NA, Lorenzen CJ (1984) Carbon-14 labeling of phytoplankton carbon and chlorophyll a carbon: determination of specific growth rates. Limnol Oceanogr 29 : $135-145$

Williams R (1988) Spatial heterogeneity and nıche differentiation in oceanic zooplankton. Hydrobiologia 167/168: $151-159$

Williams R, Hopkins CC (1976) Biological sampling at ocean weather station India $\left(59^{\circ} \mathrm{N} 19^{\circ} \mathrm{W}\right)$ in 1974 . Ann Biol Copenhagen 31:57-60

Williams R, Robinson GA (1976) Biological sampling at ocean weather station India $\left(59^{\circ} \mathrm{N} 19^{\circ} \mathrm{W}\right)$ in 1971 Ann Biol Copenhagen 28:57-59

Woods JD, Barkmann W (1986) The response of the upper ocean to solar heating-I. The mixed layer. Q J R Meteorol Soc 112:1-27

Manuscript first received: December 2, 1995

Revised version accepted: March 17, 1997 